\title{
The Effects of Organizational Assurance, Affective Commitment and Job Satisfaction on Individual Job Performances of Preschool Teachers
}

\author{
SabihaSevinç Altaş ${ }^{1}$, Ali Kuzu ${ }^{2}$ \\ ${ }^{1}$ Assist.Prof.Dr.,Sakarya University, Vocational School of Health Services, Turkey \\ ${ }^{2}$ Assist.Prof.Dr.,Sakarya University, Vocational School of Health Services, Turkey
}

\begin{abstract}
Early childhood" is the most critical period in the development of a person. Supplying the children with good education and positive environmental conditions plays a vital role in their physical, mental, emotional and social development. Of course, preschool teachers are the main actors in this learning and development process. The purpose of this study is to examine the effects of organizational assurance, affective commitment and job satisfaction on individual job performances of preschool teachers. The study covers the preschool education institutions in the province of Sakarya. The data were collected from 135 preschool teachers in 19 institutions. After the exploratory factor analysis, data were analyzed by correlation analysis and separate regression models. It was found that the positive effect of job satisfaction on individual job performance is stronger than other variables. Assurance to the manager also increases the individual job performance. On the other hand, a meaningful relation between organizational assurance and individual job performance could not be found.
\end{abstract}

Keywords: Organizational assurance, affective commitment, job satisfaction, job performance, preschool education

\section{Introduction}

The rise of competition in recent years due to globalization is also influencing the early childhood education institutions in Turkey. "Early childhood" is a critical stage that is essential to laying the foundations for a child's development of personality and growing up as a healthy individual. When a child starts to school, he has completed a major part of his development. Education is a process that starts with birth and continues throughout the life. The foundations of a lifelong learning are laid during the first six years, "early childhood". Giving children a good education and supplying a positive environment plays a key role in supporting a child's physical, mental, emotional and social development. Undoubtedly the preschool teachers are the key component to this process. For that reason, important duties are bestowed upon the business executives for maintaining the organizational climate that either exists or requested to exist. The organizational climate and the purposes of the organization that the business has are in a key position in creating harmonious attitude and behavior. Upon establishing this harmony the positive effects on variables like the employees' organizational commitment, organizational citizenship behavior, organizational loyalty, job satisfaction, organizational assurance, organizational sense of justice, work and organizational performance etc. These positive effects will ensure the firm laying of educational foundations for the children who are our future. For those reasons the subject of the research consists of affective commitment, job satisfaction, organizational confidence and individual work performance relationships. The lack of research on affective commitment, job satisfaction, organizational assurance and individual work performance relationships in preschool educational organizations in Sakarya is the reason for his research. This research is based on the analysis of the data collected from the teachers who work in preschool education organizations in Sakarya.

\section{II.1. Job Satisfaction and Affective Commitment}

\section{Theoretical Framework}

Job satisfaction is generally the result of the perception of the individual over his/herneeds, the job itself and what they get from the workplace conditions (Francies and Milbourn, 1980). Due to these perceptions, the individual gives an emotional reaction to his/herorganization. This reaction is a sense of justice or equality the individual gets from comparing his/herjob and what he/she gets out of it to his/herexpectations, desires and needs. Thanks to the comparison the perception of justice leads to job satisfaction. (Lambert, Barton and Hogan, 1999). Job satisfaction is a personal assessment of the job conditions (job itself, attitude of the management) or the results they get out of the job (wage, job security). Job satisfaction is a result of the individual's internal reactions towards the job and the perception of job conditions that is processed through the system of the individual's norms, values and expectations (Schneider and Snyder, 1975: 31). In that sense, job satisfaction is 
the employees' perception of job and the benefits of it and also an emotional response to that perception (Luthans, 1994: 114). Job satisfaction is usually considered a positive effect of the workplace experiences of the employee. If the individual receives the necessary satisfaction from the job,he/shewill have a positive attitude towards the job and the workplace (Erdoğan, 1991: 376).

Organizational commitment is the psychological commitment the individuals feel towards the organization. Commitment is a result or the interest in the job, loyalty and the strong faith in the organizational values (O'reilly, C.,1995). Organizational commitment is defined in varying ways. The definition of organizational commitment by Porter and his friends who are the most widely accepted in organizational commitment literature emphasizes the existence of three distinct traits of organizational commitment (Porter, Steers, MowdayandBoulian, 1974: 656):

i. Strong beliefs about the acceptance of goal and values of the organization,

ii. Making an effort for succeeding the goals of the organization,

iii. Strong desire to continue membership to the organization.

On the issue of organizational commitment a multidimensional organizational commitment model developed by Meyer \& Allen is known as a widely accepted and used model. In Meyer \& Allen's three factors based organizational commitment model that consists of affective, normative and compulsory commitment:

- Affective commitment is defined as interest in the organization, identifying self with the organization and embracing the goals and values of the organization.

- Compulsory commitment is the individual's commitment to the organization that is born out of the fear over financial situation that they have to endure in a scenario in which the individual is unemployed due to being removed from the organization.

- Normative commitment is a result of the perception of moral necessity about remaining in the organization and includes moral values and beliefs (Meyer, J.; Stanley, D., HerscovitchandTopolnytsky, L., 2001).

The employee prefers remaining in the organization due to feelings like loyalty, duty and obligation. (Clugston, M., 2000).While job satisfaction as a positive workplace attitude is a reaction to the individual's job and job conditions, organizational commitment describes the attitudes of the person towards the entirety of the organization (Luthans, 1994: 108-113).

\section{II.2. Organizational Assurance}

According to Matthai, assurance is the issue of organization's assistance with its corresponding words and actions, when the employees are faced with uncertainty and a risky situation (Ertürk, 2008). According toZaheervd (1998) trust is an expectation towards the other side on whether or not they will fulfill their obligations, act as the claimed they would and negotiate fairly in pragmatic situations (Tüzün, 2007). It is a concept earned as a result of the behavior based on mutual respect and courtesy for the benefit of the members of the organization (Taylor, 1989)

According to Mishra and Morrissey, organizational assurance can be developed based on four dimensions. First is open communications within the organization, second is an active role of the employees in the decision making process, third is sharing data and information and fourth is an accurate statement of feelings and expectations (Gilbert and Tang, 1998).

Strategy and policies of the organization is also effective in establishing organizational assurance. Said situation can be exemplified with the following case; According to the Milanese Kustermann who supplies a high class employee forthe organizations; "Conditions for promotion are obvious. The new recruits are told what to expect and what is expected of them. All new recruits know that we have a "grow or leave" system. If they don't show a continuous reputation increasing progress in their respective field, they will eventually leave the company. When somebody leaves, it is never a surprise because this individual has had a lot of reviews during all the years they spent in the company and every chance of benefiting the unique feedback from the chief executive or the concerning manager." As it is seen the assurance is dependent on the transparency of the strategies and policies that are pursued. The sense trust and commitment of the employee who perceives and accepts the organization this way is naturally born (Cohen andPrusak, 2001). With this example in mind, in order to establish organizational assurance, a trustworthy organization needs to be established (Demirel, 2008). Assurance is an important factor in organizational climate, employee performance and commitment to the organization. (Laschinger, FineganandShamian, 2001).

There are many different distinctions on studies relating the issue of assurance. But the most important distinction is the assurance in the individual versus the assurance in the organization (Luhman, 1979; Nyhanand Marlowe, 1997; Tan and Tan, 2000). According to Luhman (1979)'s distinction on the assurance in the individual and the assurance in the organization, assurance in the individual is based on the differences of personality and is unique to individuals, whereas the organizational assurance is more about the institutions rather than the individuals. Shockeleyet al.(2000), stated that while the assurance in the individual reflects the 
expectations from personal relationships and behaviors, assurance in the organization reflects the expectations of the individual concerning the relationships and behaviors relating the organization. The assurance in the manager which comes out of the assurance in the individual is the belief that the manager will keep their promises, be consistent and fair, give open and correct answers. (Reinke, Baldwin,2001). According to Tan and $\operatorname{Tan}(2000)$; although the assurance in the manager and the assurance in the organization are related factors, they are different concepts. They have detected that the assurance in the organization can be integrated with variables that affect the entirety of the organization like organizational support or organizational justice, whereas the assurance in the manager has a close relationship with close variables like the capabilities, respectability and generosity of the manager. They have also detected that the results of the employee's assurance in the organization and the manager. While assurance in the organization increases organizational commitment and affects employee circulation, assurance in the manager affects employee satisfaction and progressive behavior.

\section{II.3. Individual Job Performance}

Performance assessment is accepted as a helpful tool by the organization and by the employee. Performance assessment has two important goals. One of these is to acquire information about job performance, since this information will be useful while making managerial decisions. Decisions relating to wage increases, bonuses, education, discipline, promotions, career planning and other managerial activities are based on the information gathered by the performance assessment. A managerial board of an organization should not make managerial decisions without the decisions made in the performance assessment. Like other policies relating to human resources, performance assessment too is based on legal standards blocking discrimination against any particular group (Micolo, 1993).

The second goal of performance assessment is to receive feedback on how close are the employees to the standards determined in the job descriptions of the employees and job analyses. This feedback, when delivered to the employees in a positive way and supported with professional education, can be very useful. Most employees would like this sort of constructive and confidence increasing feedback. This feedback will also help the employees see what direction their careers gowithin the organization. For example, it would show if the employee is ready to take a greater responsibility or if the employee needs education to sustain their current status. (Palmer, 1993)

According to Paşa (2007), there are three factors that make the individual performance:

i. Focusing: First step to increase individual performance is to ensure focus. In working life, performance, also known as success has nothing to do with luck. There are no ways to success with general acceptability like being in the right place at the right time or knowing the right person. Maybe these would help. The real performance can only be acquired by knowing how to prepare for it. What that means in the workplace is having a developed method for knowing who should do what and when.

ii. Qualification: Qualification is called the talent, knowledge and skill that lead to better performance. Talent comes with birth. Skill comes with experience. According to another definition qualifications are behavioral groups that include traits like personality, organization, interest and motivation. The qualifications are the actions that the employees take with knowledge, skill and attitudes that they have developed with compatibility to the beliefs and values system in order to get organization, department and personal results.

iii. Dedication: Dedication is the process of the employee identifying themselves with the business that they are in and make their own goals compatible to the organization's goals in order to help the business reach its goals and feel the need tostay longer in the business (Büte, 2011).

According to Hume, performance management is a systematically developed approach to manage human resources. This approach contains the motivation of the human resources of an organization, in order to motive them to realize their maximum performance (Özmutaf, 2007).

\section{II.4. The Effects of Affective Commitment, Job Satisfaction and Organizational Assurance on Individual Job Performance}

Studies about organizational commitment have indicated that the commitment has positive influences over organizational effectiveness and productivity and job performance (Meyer, J.et al., 2001, Steers, R.M., 1977, Porter L. et al., 1974). Chaw(1944) states that the high level of commitment leads to more responsibility, more loyalty and a higher productivity most of the time. An employee with a high performance wanting to stay in the organization increases organizational productivity. Since they put an effort with high level of organizational commitment, they do not consider leaving. (Çöl G. 2004)

Studies have shown that amongst the factors of organizational commitment; affective commitment and performance have a stronger positive relationship than normative commitment and performance and a negative relationship between obligatory commitment and performance (Meyer J.; Becker, T. andVandenberghe, C. 2004). 
Aryee and Heng (1990) have shown with their studies that there is not a strong enough connection between commitment and performance. Similarly Zajac (1990), after stating that this relationship is weak, pointed out that the most important reasons for this weak relationship are economic circumstances and expectations and family obligations. While high financial expectations (like high salary, social facilities, reward and premiums) affects organizational commitment and performance negatively, financial expectations being low affects it positively. According to Becker (1996), one of the reasons for a weak relationship between commitment and performance is that the commitment to the manager and the organizational commitment are very much integrated. A manager's care for performance and a fair assessment of performance can increase organizational commitment and performance(Gül, M. \&İnce, H. (2005).

When the relationship between performance and job satisfaction is considered, most researchers have an acceptance that job satisfaction is an important issue understanding the organizational effectiveness and the relationship between job satisfaction and performance is positive (Organ, D.W.,1988, Rusbelt, F. \& Rogers, M. 1988, Saari, L. \& Judge, T. 2004).

Judge, Thoresen, Bono and Patton (2001) who analyzed the last 301 studies on the relationship between job satisfaction and performance concluded that there is a high correlation between satisfaction and performance. The relationships between job satisfaction and performance are even more so in more complex jobs (Saari, L. and Judge, T. 2004). When employees like their jobs and have high levelsof job capabilities, there is a clear relationship between job satisfaction and efficiency (Mullins, L.J. 1993). From a positive perspective, the individual who experiences job satisfaction is more prone to pro-social behavior like helping other employees, clients and more open to cooperation. As a result, many organizational behavior researchers express the importance of job satisfaction and the importance of it to organizational efficiency to managers. On the other side, low job satisfaction may have a lot of negative effects on the organization(Luthans, F., 1994).

A research done in Gaziantep on 298 people by Büte (2011) has shown that trust has a positive influence over performance. Yousef (2000:15) and Uygur (2007:81) have stated that organizational commitment and performance has a positive but weak relationship. Altaş and Çekmecelioğlu's (2007:54) study has proven that the affective and normative commitments positively affect job performance and normative commitment has a stronger influence.

\section{III.1. Methodology of Research}

\section{Research Methodology and Findings}

Polls have been used as the data collection tool in the research. In the survey form there have been questions asked relating to each one of the variables in the research model. A 5-pointLikert-type scale has been used. Levels of agreement within the scale are $1=$ absolutely disagree, $2=$ partly disagree, $3=$ undecided, $4=$ partly agree, 5=absolutely agree. The data has been collected between September 2012 and February 2013 by the researcher. Evaluation of the research data was done by SPSS 16.0 for Windows statistics package program. The data was analyzed for factor analysis, reliability, correlation and regression, made a frequencydistribution for demographic variables, calculated the average and standard margin of error.

In the research, 4 questions concerning the "affective commitment" variable have been adapted from the research of Meyer and Allen (1991), 5 questions concerning "job satisfaction" have been adapted from Rusbelt, Farrell, Rogers veMainous (1988), 12 questions concerning "organizational assurance" from Nyhan and Marlowe (1997) and 4 questions concerning individual job performance from Kirkman and Rosen (1999). Questions concerning the relationship between affective commitment, job satisfaction, organizational assurance and individual performance have been classified under 5 factors. These factors and questions concerning them are affective commitment, job satisfaction, and organizational assurance over the assurance in the manager and the organization and individual job performance.

\section{III.2. Research Model and Hypotheses}

This research concerning the relationship between affective commitment, job satisfaction, organizational assurance and individual performance, affective commitment, job satisfaction and organizational assurance relating to the assurance in the manager, dimensions of the assurance in the organization and individual performance variables have been used.

There have been five variables in the research. As the independent variable affective commitment, job satisfaction and assurance in the manager and the organization have been used. The independent variable is the individual job performance. The hypotheses to be tested in the research are the following:

Hypothesis 1: Affective commitment has a positive effect on individual job performance.

Hypothesis 2: Job satisfaction has a positive effect on individual job performance.

Hypothesis 3:Assurance in the manager has a positive effect on individual job performance.

Hypothesis 4: Organizational assurance has a positive effect on individual job performance. 


\section{III.3. Findings}

\section{III.3.1. Demographic Characteristics}

As it is seen in Table-1, out of 135 employees who responded to the polls, $0.74 \%$ are men, $99.25 \%$ are women. $58.7 \%$ of the participants are married, $38.4 \%$ are single. $65.9 \%$ are 1 to 5 years, $18.8 \%$ are 6 to 10 years, $4.3 \%$ are 11 to 15 years, and $5.1 \%$ are over 16 years of seniority. $95.7 \%$ of the participants have undergraduate and $2.2 \%$ have graduate degrees. $63 \%$ of the participants work in educational institutions with fewer employees than 50, 25.4\% work in educational institutions above 50 employees. $47.8 \%$ are below the age of $30,35.5 \%$ are between 31 and $35,7.2 \%$ are 36 to $40,4.3 \%$ are 41 to 50 and $2.9 \%$ are over 50 .

Table1.Demographic Properties of the Sample

\begin{tabular}{|c|c|c|c|c|c|}
\hline & Frequency & Percentage & & Frequency & Percentage \\
\hline $\begin{array}{l}\text { GENDER } \\
\text {-Male } \\
\text {-Female }\end{array}$ & $\begin{array}{l}1 \\
134\end{array}$ & $\begin{array}{l}.74 \\
99.25\end{array}$ & $\begin{array}{l}\text { MARITAL STATUS } \\
\text {-Married } \\
\text {-Single }\end{array}$ & $\begin{array}{l}81 \\
53\end{array}$ & $\begin{array}{l}58.7 \\
38.4\end{array}$ \\
\hline $\begin{array}{l}\text { LENGTH of SERVICE } \\
1-5 \text { years } \\
6-10 \text { years } \\
11-15 \text { years } \\
16+\text { years }\end{array}$ & $\begin{array}{l}91 \\
26 \\
6 \\
7\end{array}$ & $\begin{array}{c}65.9 \\
18.8 \\
4.3 \\
5.1\end{array}$ & $\begin{array}{l}\text { AGE } \\
\text { - Less than } 30 \\
-30-35 \\
-36-40 \\
-41-50 \\
-50+\end{array}$ & $\begin{array}{r}66 \\
49 \\
10 \\
6 \\
4\end{array}$ & $\begin{array}{r}47.8 \\
35.5 \\
7.2 \\
4.3 \\
2.9\end{array}$ \\
\hline $\begin{array}{l}\text { NUMBER of EMPLOYEES } \\
\text {-Less than } 50 \\
-50-100\end{array}$ & $\begin{array}{l}87 \\
35\end{array}$ & $\begin{array}{l}63.0 \\
25.4\end{array}$ & $\begin{array}{l}\text { EDUCATION } \\
\text {-University Graduate } \\
\text {-Masters/PhD }\end{array}$ & $\begin{array}{r}132 \\
3\end{array}$ & $\begin{array}{c}95.7 \\
2.2\end{array}$ \\
\hline
\end{tabular}

\section{III.3.2. Factor Analysis Concerning the Research Variables}

In this part of the research statements relating the five variables within the model have gone through factor analysis. Within the model there have been 24 statements concerning the factors of affective commitment, job satisfaction, assurance in the manager, organizational assurance and individual work performance. The analysis results concludes the KMO value came out $0.900>0.5$. There are five variables in the research model. Questions concerning said variables and factors that are in the polls are shown in detail in Table 2.

Table2.Factor Analysis Results Concerning the Research Variables

\begin{tabular}{|c|c|c|c|c|c|}
\hline & Affective Commitment & Job Satisfaction & Managerial Assurance & Organizational Assurance & Individual Job Performance \\
\hline 1. I will be happy to work in this organization during my remaining career &, 733 & & & & \\
\hline 2. I feel the problems of my organization as my own problems &, 786 & & & & \\
\hline 3. This organization has a personal meaning for me & 591 & & & & \\
\hline 4. I talk proudly about my organization, outside &, 676 & & & & \\
\hline 1. My job pleases me, when think about all the conditions & & 684 & & & \\
\hline 2.Ilove myjob & & 636 & & & \\
\hline 3. I advise my job to anybody & & 737 & & & \\
\hline 4. My current job fits with my ideal job of my dreams & & 804 & & & \\
\hline 5.My current job complies with my expectations when I started to work here. & & 841 & & & \\
\hline $\begin{array}{l}\text { 1. My assurance to my manager is full about his her technical adequacy about } \\
\text { important topics related with his her job }\end{array}$ & & & 834 & & \\
\hline 2.My assurance to my manager's well considered decisions is full & & & .805 & & \\
\hline 3. My assurance is full to my manager that he she will not leave the job & & & .698 & & \\
\hline 4. My assurance is full to my manager's apprehension to a reasonable extend & & & 881 & & \\
\hline 5.My assurance is full to my manager that he she reasonably does his job & & & .853 & & \\
\hline 6. My assurance is full to the rightfullness of what my manager tells, at any topic & & & .763 & & \\
\hline $\begin{array}{l}\text { 7. My assurance is full to my manager that he she can perform his her job } \\
\text { without causing any other problems }\end{array}$ & & & .860 & & \\
\hline $\begin{array}{l}\text { 8. My assurance is full to my manager that he she thinks carefully about what } \\
\text { he she does }\end{array}$ & & & .866 & & \\
\hline $\begin{array}{l}\text { 1. The assurance level between the managers and the employees is quite high in } \\
\text { this organization }\end{array}$ & & & & 873 & \\
\hline 2. The assurance level between the people whom I am working with is quite high & & & & 932 & \\
\hline 3. The assurance level among us in this organization is quite high & & & & 919 & \\
\hline 1. I always complete my duties on time & & & & & .872 \\
\hline 2. I realize or exceed my goals & & & & & .904 \\
\hline 3. I quickly solve if there is a problem & & & & & .877 \\
\hline 4. I exactly produce at over quality standards & & & & & .871 \\
\hline
\end{tabular}

$\mathrm{KMO}=0.900>0.5 \quad$ Barlett's Test $\mathrm{p}=0,00 \quad$ Percentage of the total variance explained $=71.13$

\section{III.3.3. Analysis Results about Variables}

Average, standard deviation and Pearsoncorrelations concerning all the variables are presented in Table 3. As it is seen in this chart, there is a $1 \%$ meaningful positive relationship between individual job 
performance and affective commitment, job satisfaction and assurance in the manager and organizational assurance. The relationship between affective commitment and the variable assurance in the manager is stronger than the relationship in assurance in the organization. However, although there is $1 \%$ meaningful positive relationship between assurance in the manager and individual job performance, there is no evidence of meaningful relationship between assurance in the organization and individual job performance.

Table3.Average, standard deviation and pearson correlations concerning all variables

\begin{tabular}{|l|l|l|l|l|l|l|l|}
\hline & Ort. & S.S. & 1 & 2 & 3 & 4 & 5 \\
\hline 1.Affective commitment & 4,10 &, 77 &, $642(\mathrm{a})$ &, $427^{* *}$ &, $403^{* *}$ &, $278^{* *}$ &, $263^{* *}$ \\
\hline 2. Job satisfaction & 4,23 &, 74 & &, $795(\mathrm{a})$ &, $365^{* *}$ &, $343^{* *}$ &, $549^{* *}$ \\
\hline 3. Assurance in the manager & 3,957 &, 72 & & &, $949(\mathrm{a})$ &, $561^{* *}$ &, $268^{* *}$ \\
\hline 4. Organizational assurance & 3,735 &, 95 & & & &, $938(\mathrm{a})$ &, 152 \\
\hline 5. Performance & 4,208 &, 65 & & & & & \\
\hline
\end{tabular}

*Meaningful (both side) at .05 level ** Meaningful (both side) at .01 level

Table4.Pearson Correlations Related to Variables and Demographic Characteristics

\begin{tabular}{|l|l|l|l|l|l|l|}
\hline & Age & Gender & Marital Status & Education & Length of Service & Number of Employees \\
\hline 1.Affective commitment &, $193^{*}$ &, 050 &,- 161 &,- 019 &, $176^{*}$ &, 055 \\
\hline 2. Job satisfaction &, 076 &, 035 &, 008 &,- 009 &, 069 &, 066 \\
\hline 3. Assurance in the manager &,- 034 &, $342^{* *}$ &, 139 &, 009 &, 001 &,- 093 \\
\hline 4. Organizational assurance &,- 039 &, $192^{*}$ &, 057 &, 044 &,- 141 &,- 025 \\
\hline 5. Performance &, 132 &,- 040 &,- 114 &,- 50 &, 103 &,- 008 \\
\hline
\end{tabular}

*Meaningful (both side) at .05 level ** Meaningful (both side) at .01 level

Demographic variables and the relationships between affective commitment, job satisfaction, organizational assurance and individual performance have been evaluated. Affective commitment and age, seniority has a positive 5\% relationship. Findings on gender are remarkable. There is a $1 \%$ positive relationship between gender and assurance in the manager. There is a 5\% positive relationship between gender and assurance in the organization.

Table 5: Effect of Affective Commitment on Individual Job Performance

\begin{tabular}{|l|l|}
\hline Independent Variables & $\begin{array}{l}\text { Individual Job Performance } \\
\text { Model 1 }\end{array}$ \\
\hline & $\square$ \\
\hline Affective Commitment & $, 263 \quad 3,091 * *$ \\
\hline Model F & 9,555 \\
Model R &, 0069 \\
\hline$* * \mathrm{p}<.01 * \mathrm{p}<.05$ (single sided) & \\
\hline
\end{tabular}

Table6: Effect of Job Satisfaction on Individual Job Performance

\begin{tabular}{|l|lc|}
\hline & \multicolumn{2}{|l|}{ Individual Job Performance } \\
\hline & Model 2 & \multicolumn{1}{c|}{} \\
\hline & $\square$ & $7,517^{* *}$ \\
\hline Job satisfaction & .549 & \\
\hline Model F & $56,501 * *$ \\
Model R & 0.301 & \\
\hline$* * \mathrm{p}<.01 * \mathrm{p}<.05$ (single sided) & & \\
\hline
\end{tabular}

Table 7: Effects of Assurance in the Manager and Assurance in the Organization Dimensions on Individual Job Performance

\begin{tabular}{|l|lc|}
\hline & \multicolumn{2}{|l|}{ Individual Job Performance } \\
Independent Variables & Model 3 & t \\
\hline & $\square$ & $2,371 * *$ \\
\hline Assurance in the Manager & .249 &, 155 \\
\hline Assurance in the Organization & .016 & \\
\hline Model F & $4,383^{* *}$ & \\
Model $\mathrm{R}^{2}$ & 0,067 & \\
\hline$* * \mathrm{p}<.01 * \mathrm{p}<.05$ (single sided) & & \\
\hline
\end{tabular}

\section{III.3.4. Hypotheses Test Results}

The test results of the hypotheses of the research are summarized in Table- 8 .

Table 8: The Results of the Tested Hypotheses

\begin{tabular}{|l|l|}
\hline & Result \\
\hline Hypothesis 1: Affective commitment has a positive effect on individual job performance. & Accepted \\
\hline
\end{tabular}




\begin{tabular}{|l|l|}
\hline Hypothesis 2: Job satisfaction has a positive effect on individual job performance & Accepted \\
\hline Hypothesis 3: Assurance in the manager has a positive effect on individual job performance. & Accepted \\
\hline Hypothesis 4: Organizational assurance has a positive effect on individual job performance. & Rejected \\
\hline
\end{tabular}

\section{Result and Suggestions}

In this research the relationship between preschool teachers' affective commitment, job satisfaction and assurance in the manager and the organization has been observed. The research results show the strong and positive influence of affective commitment, job satisfaction, assurance in the manager and the organization on the individual job performance. The results match with similar researches in the literature (Büte,2011)

The positive influence of the assurance in the manager on the individual job performance has been detected. This means the more the preschool teachers trust their managers more their individual job performance will be. However there has been no sign of meaningful findings in the research about organizational assurance's influence on the individual job performance.

When the effect of job satisfaction on job performance is studied, both the correlation and the regression analyses show that people being satisfied with what they do increases individual job performances. When organizational commitment factors' influence on individual job performance are observed, correlation and regression analyses have shown that affective commitment has positively influenced job performance. The researches that Meyer and friends did (2001) in North America have shown that affective commitment has an even greater influence on job performance. For that reason business executives who are looking to improve organizational performance should show an interest in managerial decisions that increase organizational assurance, job satisfaction and affective commitment which increase job performance.

\section{Acknowledgements}

The authors express their sincere appreciation to the developers of the theoretical background of the topic and the former scholars. The authors read and approved the final manuscript.

\section{References}

[1]. Francis, Glenn James, and Gene Milbourn. Human behavior in the work environment: A managerial perspective. (Goodyear Publishing Company, 1980).

[2]. Lambert, Eric G., Shannon M. Barton, and Nancy Lynne Hogan. "The missing link between job satisfaction and correctional staff behavior: The issue of organizational commitment." American Journal of Criminal Justice 24.1 1999: 95-116.

[3]. Schneider, Benjamin, and Robert A. Snyder. "Some relationships between job satisfaction and organization climate." Journal of applied psychology 60.3, 1975, 318.

[4]. Luthans F., Organizational Behavior(Newyork: McGraw-Hill Inc. 1994),

[5]. $\quad$ Erdoğan İ..IşletmelerdeDavranış(İ.Ü. İşletmeFakültesiYayın No: 242, İstanbul. 1991)

[6]. O'reilly, C.Corporations, Culture and Commitment:Motivation and Social Control in Organizations. Psychological Dimensions of Organizational Behavior(Ed.: Staw, B.M,2nd Ed., New Jersey: Prentice Hall. 1995)

[7]. Porter, L.; Steers, R.; Mowday, R. \&Boulian, P, Organizational Commitment, Job Satisfaction, and Turnover amnong Psychiatric Technicians. Journal of Applied Psychology, 59(5), 1973, 603-609.

[8]. Meyer, J.; Stanley, D.,Herscovitch\&Topolnytsky, L, Affective, Continuance, And Normative Commitment tothe Organization: Meta Analysisof Entecedents,Correlates and Consequences. Journal of Vocational Behavior, 61(1), 2001, 20-52.

[9]. Clugston, M., Does Cultural Socialization Predict Multiple Bases and Foci of Commitment? Journal of Management, 26(1), 2000, $5-30$.

[10]. Ertürk, A., A trust-based approach to promote employees openness to organizational change in Turkey. International Journal of Manpower, Vol. 29- 5, 2008, 462- 483

[11]. Tüzün, İ.K.,Güven, Örgütsel Güvenve Örgütsel Güven Modelleri. Karamanoğlu Mehmetbey Üniversitesiİktisadiİdari Bilimler Fakültesi Dergisi,2007, 93-118

[12]. Taylor R.G,The Role of Trust in Labor-Management Relations. Organization Development Journal, 7,1989, 85-89.

[13]. Gilbert, J.A.\&TANG T.L, An Axamination of Organizational Trust Antecedents. Public Personnel Management, 27(3), 1998, 321338

[14]. Cohen, D. vePrusak, L. Kavrayamadığımız Zenginlik, Kuruluşların Sosyal Sermayesi (Çev. A. Kardam, İstanbul: BZD Yayınvelletişim Hizmetleri, 2001)

[15]. Demirel, Y,ÖrgütselGüveninÖrgütselBaglılıkÜzerineEtkisi: TekstilSektörüÇalısanlarınaYönelikBirArastırma. Celal Bayar Üniversitesi İ.̇.B.F. YönetimveEkonomiDergisi, 15,2,2008, 179-196

[16]. Laschinger HKS, Finegan J, Shamian J, and Wilk P, Impact of structural and psychological empowerment on job strain in nursing work settings: Expanding Kanter's model. Journal of Nursing Administration 31, 2001, 260-72

[17]. Luhmann, N. Trustand Power: two works by NiklasLuhmann. (Chichester: Wiley, 1979)

[18]. Nyhan, R. C., \& Marlowe, H. A, Development and psychometric properties of the organizational trust inventory. Evaluation Review, 21(5), 1997, 614-635.

[19]. Tan, H.H., Tan, C.S, Toward the Differentiation of Trust in Supervisor and Trust in Organization. Genetic, Social and Psychology Monographs, 126(2),2000, 241-260

[20]. Shockley-Zalabak, P., Ellis, K., \&Winograd, G, Organizational trust: What it means, why it matters. Organization Development Journal, 18, 2000, 35-48

[21]. Reinke, S. J., Baldwin J.N,Is Anybody Listening? Performance Evaluation Feedback in the U.S. Air Force. Journal of Political and Military Sociology, 29(1),2001, 160-176

[22]. Micolo A.M, Suggestions for Achieving a Strategic Partnership. HR Focus, Vol.70, No:9, 1993, 22

[23]. Palmer, M.J. PerformansDeğerlendirmeleri(Rota Yayınları, 1.Baskı, 1993) 
[24]. Paşa, Muammer., Stresin Bireysel Performans Üzerindeki Etkilerive Bir Uygulama, doctoraldiss. Uludağ Üniversitesi Sosyal Bilimler Enstitüsü, BasılmamışDoktoraTezi, Bursa-2007.

[25]. Büte, M,Etikİklim, ÖrgütselGüvenveBireyselPerformansArasındakiİlişki. İktisadiveİdariBilimlerDergisi, 25 (1), 2011

[26]. Özmutaf N.M,ÖrgütlerdeBireyselPerformansUnsurlarıveÇatışma. C. ̈̈. ÍktisadiveİdariBilimlerDergisi, Cilt 8, Sayı 2, 2007, 41-61

[27]. Steers, R.M., Antecedents and outcomes of organizational commitment, Administrative. Science Quarterly, 22(1), 1977, 46-56.

[28]. Porter, Lyman W., et al. "Organizational commitment, job satisfaction, and turnover among psychiatric technicians." Journal of applied psychology 59.5,1974, 603.

[29]. Çöl, G. Güçlendirmeve Örgütsel Bağlllıkillişkisi Üzerine Bir Araştırma, doctoral diss.GebzeYüksekTeknolojiEnstitüsü: YayınlanmamışDoktoraTezi. 2004

[30]. Meyer J.; Becker, T. \&Vandenberghe, C., Employee Commitment and Motivation: A conceptual analysis and Integrative Model. Journal of Applied Pschology, 89(6), 2004, 991-1007.

[31]. Gül, M. \&İnce, H. YönetimdeYeniBirParadigma: ÖrgütselBağlılık(Konya: ÇizgiKitapevi. 2005)

[32]. Organ, D.W. Organizational Citizenship Behavior: The Good Soldier Syndrome(Lexington. MA: Lexington Books. 1988)

[33]. Rusbelt; F. \& Rogers; M, Impact Of Exchange Variables On Exit, Voice, Loyalty And Neglect: An İntegrative Model Of Responses To Decline Job Satisfaction. Academy of Management Journal, 31(3), 1988, 599-627.

[34]. Saari, L. \& Judge, T, Employee Attitudes and Job Satisfaction. Human Resource Management, 43(4), $2004,395-407$.

[35]. Yousef, Darwish A., "Organizational Commitment: a Mediator of the Relationships of Leadership Behavior with Job Satisfaction and Performance in a Non-Western Country", Journal of Managerial Psychology, Vol. 15, No. 1, 2000, 6-24.

[36]. Uygur, Akyay, "ÖrgütselBağlılıkileİşgörenPerformansillişkisinil̈ncelemeyeYönelikBir Alan Araştırması", TicaretveTurizmĔ̈itimFakültesiDergisi, Sayı: 1, 2007, 71-85.

[37]. Altaş, SabihaSevinç, Çekmecelioğlu, Gündüz, Hülya, "İşTatmini, Örgütsel Bağlılıkve Örgütsel Vatandaşlık DavranışınınI̦ Performansı Üzerindeki Etkileri: BirAraștırma”, Öneri, C.7. S.28, 2007, 47-57.

[38]. Kirkman, B. L., Rosen, B., Tesluk, P. E., \& Gibson, C. B, The impact of team empowerment on virtual team performance: The moderating role of face-to-face interaction. Academy of Management Journal, 47(2), 2004, 175-192. 